\section{MATERIALS}

\section{On Boom and Doom}

from our Materials Science Correspondent A RECENT public venture by Harvey Brooks, professor of applied physics at Harvard University, was a lecture on materials in a steady state world, delivered last autumn to the two leading professional bodies in American metallurgy, and now published in their joint journal (Metallurgical Trans., 3, 759 ; 1972). Professor Brooks is a man of unusually wide experience in the borderlands of science, engineering and politics in the United States, and has participated in many enquiries on various aspects of science policy.

$\mathrm{He}$ began with a thumbnail sketch of Forrester's world models (the lecture antedated publication of The Limits to Growth, which took that model a stage further), and contrasted the underlying outlook of that form of global future gazing with the changes during the past century in the supply and real price of raw materials, bearing in mind the fact that dire prophecies of the exhaustion of natural resources have been current for a long time-they were particularly prevalent in the first two decades of this century. Among a number of striking observations, he showed that the consumption of materials per capita had grown much less rapidly than the gross national product (GNP) per capita, and that the output for each man employed has risen particularly fast in the mineral extraction industries. He made the intriguing suggestion that one symptom of the lack of pressure on these industries has been the sharp decline of mining engineering and extractive metallurgy in universities.

Having very fairly presented the optimist's case, Professor Brooks then turned to the other side of the medal. Some materials pose a much more serious problem than others: thus per capita use of paper is closely correlated with per capita GNP, but grows five times for each doubling of the per capita GNP. Moreover, the price in real terms of forest products has trebled over the past century, whereas on the same basis the prices of minerals are unchanged. Professor Brooks went on to classify metal ores in a particularly illuminating way. Some metals, especially iron and aluminium, are present in enormous quantities in ores whose grade varies from those at present exploited, continuously down to very much lower levels. Others, such as $\mathrm{Cu}, \mathrm{Ni}, \mathrm{V}, \mathrm{Pb}$, occur in ores with a continuous range of grades, including substantial supplies in ores at present somewhat too lean to use, and these will become steadily dearer without, presumably, a state of crisis being reached. The real problem comes with what he calls the "metal vitamins", used

as essential alloying elements; these include, among others, $\mathrm{Hg}, \mathrm{W}, \mathrm{Ta}, \mathrm{Ag}$, $\mathrm{Sn}, \mathrm{Mn}$ and Mo; some of these of course have "nutrient" as well as "vitamin" uses. They are won from rich mineral veins which are fast being exhausted, but once this has happened, there is apparently no supply of progressively leaner ores, only the general background concentration in the Earth's crust, which is orders of magnitude lower.

Many metals can be won for a long time by a combination of improved technology and higher real price, but this will not be true for all. When one of the problem metals also poses a special pollution problem, it will be interesting to see how rapidly substitution or abolition of function results. Mercury is a good example, and it may be significant that the price has recently been plummeting: on the other hand, the influences of cartels among producers and consumers are so strong that it is dangerous to read too much into price fluctuations of metals.

Professor Brooks continued by outlining some of the more novel problems of the future, which are all connected with the increasing difficulty of discerning trends far enough in advance to plan the necessary industrial changes in the extractive industries. $\mathrm{He}$ instances sudden unpredictable political changes, including ever stronger cartels of suppliers, and changes imposed by rapidly veering public opinion, which do not allow the necessary lead time for technical change. $\mathrm{He}$ also assessed in general terms the problems arising out of the universal drive towards growth, and said quite bleakly that "there

\title{
Factor Regulating Translation of RNA Coliphages
}

IN Nature New Biology next week (September 6) Revel and various colleagues describe in two reports the discovery of a new control element which seems to play a part in regulating the translation of particular cistrons of a messenger RNA and which also comprises one of the polypeptide chains of phage $Q \beta$ RNA replicase. The new factor is designated by Groner, Pollack, Berissi and Revel as factor i because it appears to interfere with the translation of the coat protein cistron of the RNA phage MS2 by binding to the chain initiation factor 3.

In the absence of interference factor $i$, initiation factor 3 promotes the efficient translation of the MS2 coat protein cistron in vitro, but when factor $\mathrm{i}$ is added synthesis of coat protein is markedly reduced while translation of the RNA synthetase cistron is enhanced. Factor $\mathrm{i}$ also apparently stimulates the translation in vitro of some phage $\mathrm{T} 4$ cistrons while inhibiting the translation of others so that the net result is little appears to be a major discontinuity between current trends and national objectives, in virtually all national economies, and the need to obtain some sort of equilibrium with our environment. It is not obvious that the various homeostatic mechanisms of the world economy will operate to set in motion automatically the forces which will propel us towards a new equilibrium. The discontinuity between current trends and goals and ultimate necessities is very hard to think about in a logically consistent way. The apocalyptic rhetoric of the ecological ideologies is not very helpful because they do not tell us how to get there from here, or even how to begin".

In a tentative attempt at propounding some solutions, he urged a government financed expansion of long range geochemical and geophysical research "aimed at defining and assessing the future availability of metallic ores", research which cannot fairly be left to mining firms. He thinks that, although substitution of more common for less common materials must continue apace, whole technologies must give way to less materials-intensive ones: he gave as an example advanced telecommunications as a substitute for travel. $\mathrm{He}$ also emphasized the role of draconian changes in national laws to oblige all companies to do what no one firm could do in isolation without going out of business, and instanced the new American car exhaust emission laws as an example of what can be achieved. This law may well in retrospect mark a watershed, showing many who now induge in fashionable despair what man can do to help himself.

or no change in the total protein synthesis; there is, however, a change in the relative proportions of particular proteins. Clearly factor $i$ has the properties of an element which might play an important role in regulating the expression of the Escherichia coli genome and the genomes of coliphages.

But perhaps even more intriguing than the role of factor $i$ in translation is the discovery, reported by Groner, Scheps, Kolakofsky and Revel, that factor $i$, a polypeptide with a molecular weight of 74,000 daltons, is one of the three polypeptide chains specified by the host $E$. coli genome which, together with the chain specified by the $Q \beta$ RNA synthetase cistron, comprise the $Q \beta$ RNA replicase. Apparently factor i first promotes the translation of the synthetase cistron of an RNA phage and then becomes incorporated into the synthetase molecule, an enzyme which, it should be remembered, has also been shown to act as a translational represser of the $Q \beta$ coat protein cistron. 